\title{
LITERATURE REVIEW OF OPTIMIZATION TECHNIQUES FOR CHATTER SUPPRESSION IN MACHINING
}

\author{
Ahmad RazlanYusoff ${ }^{1}$, Mohamed Reza Zalani Mohamed Suffian ${ }^{2}$ \\ and Mohd Yusof Taib ${ }^{2}$ \\ ${ }^{1}$ Faculty of Manufacturing Engineering \\ Universiti Malaysia Pahang, \\ 26600 Pekan, Pahang, Malaysia \\ Phone: +609-4242208, Fax: +609-4242202 \\ Email: razlan@ump.edu.my \\ ${ }^{2}$ Faculty of Mechanical Engineering \\ Universiti Malaysia Pahang \\ 26600 Pekan, Pahang, Malaysia
}

\begin{abstract}
Chatter produces a poor surface finish, high tool wear, and can even damage machine tools because of the regenerative effect, the loss of contact effect, and the mode coupling effect. Various research works have investigated the suppression of chatter by either passive or active methods, such as by applying absorbers, damping, varied speeds and other alternatives. In this paper, it can be observed that for chatter suppression, optimization focuses on spindle design, tool path, cutting process, and variable pitch. Various algorithms can be applied in the optimization of machining problems; however, Differential Evolution is the most appropriate for use in chatter suppression, being less time consuming, locally optimal, and more robust than both Genetic Algorithms, despite their wide applications, and Sequential Quadratic Programming, which is a famous conventional algorithm.
\end{abstract}

Keywords: Chatter; optimization; artificial intelligence; suppression.

\section{INTRODUCTION}

Almost 100 years ago, Taylor described machine tool chatter as the "most obscure and delicate of all problems facing the machinist" (Stephenson \& Agapiou, 2006). Its documented history started from as early as 1906 when chatter was recognized as a challenging practical problem. Merchant (1945) presented the kinematics of the mechanics of the orthogonal metal cutting process, as presented in Figure 1. The relationships between the forces and the cutting parameters $\varphi$, rake angle $\alpha$, the coefficient of friction $\mathrm{F}_{\mathrm{s}}$ between the tool and the chip, and the shear strength of the material $\psi$ are derived. However, the relationships are not valid in a steady state cutting process, because metal cutting is a dynamic process and chatter needs to be taken into account as it causes serious problems in machining stability. Aerospace, automotive, mold/die and general manufacturing industries face pressures to ensure lower costs, greater productivity, and improved quality, in order to encourage economic growth of the machine tool industry. However, machining productivity using high material removal rates is inhibited by the dynamic deflection of the tool and workpiece systems, which generates an unstable cutting force. This causes sudden vibrations of large amplitude when the energy input exceeds the energy dissipated from the system, which 
is known as chatter. Chatter is a self-excited type of vibration that occurs in metal cutting if the chip width is too large with respect to the dynamic stiffness of the system, especially when machining with a high material removal rate. It produces a poor surface finish, high tool wear, and can even damage machine tools because of the regenerative effect, the loss of contact effect, and the mode coupling effect. The boundary of stability limits represents either the stable or unstable (chatter) condition of the machining process and is known as the stability diagram, which is a function of depth of cut and spindle speed, as shown in Figure 2.

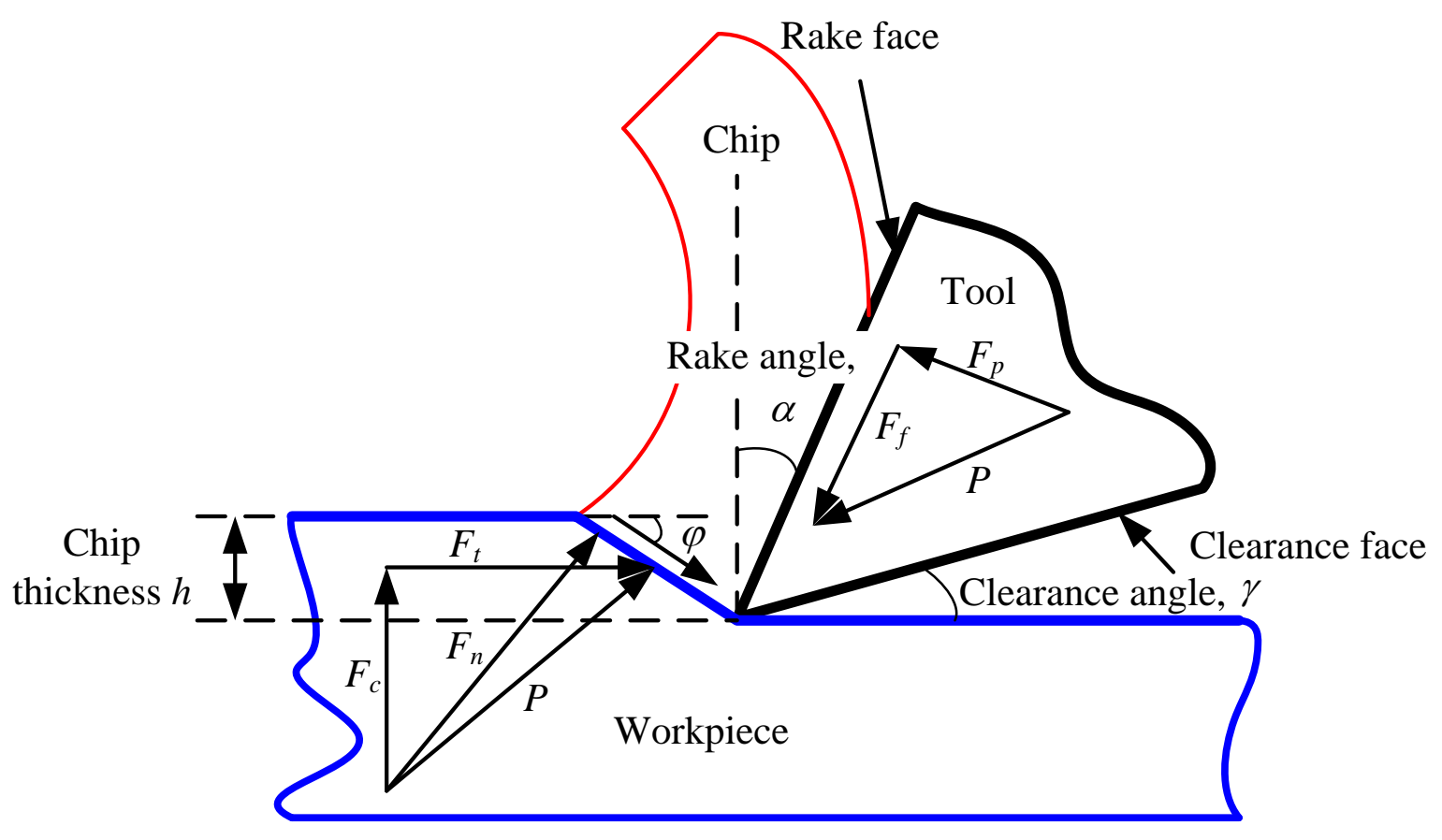

Figure 1. Model of metal cutting by Merchant (1945)

Since Taylor first developed machining techniques, researchers have given much attention to machining processes (Stephenson \& Agapiou, 2006). For the milling process, Figure 3 shows that the process parameters important in roughing or finishing operations are the axial depth of cut $b$, radial depth of cut $r$, spindle speed $n$, cutting velocity $v$, and chip width $w$. The interactions between these process parameters, machine tools, and the system cause machining problems, such as low productivity, short tool life, poor surface roughness, chatter, and others. To overcome these problems, it is necessary and important to obtain a global optimum strategy. All factors relating to each other must be considered simultaneously in order to obtain the optimal cutting parameters for accomplishing high productivity, high quality, and profit. Recent practices based on operator experience and handbooks were used as reference for optimizing the process parameters. In this paper, the algorithms or methods applied to various problems in machining optimization will be introduced and then specific focus will be placed on the problem of optimization for chatter suppression. 


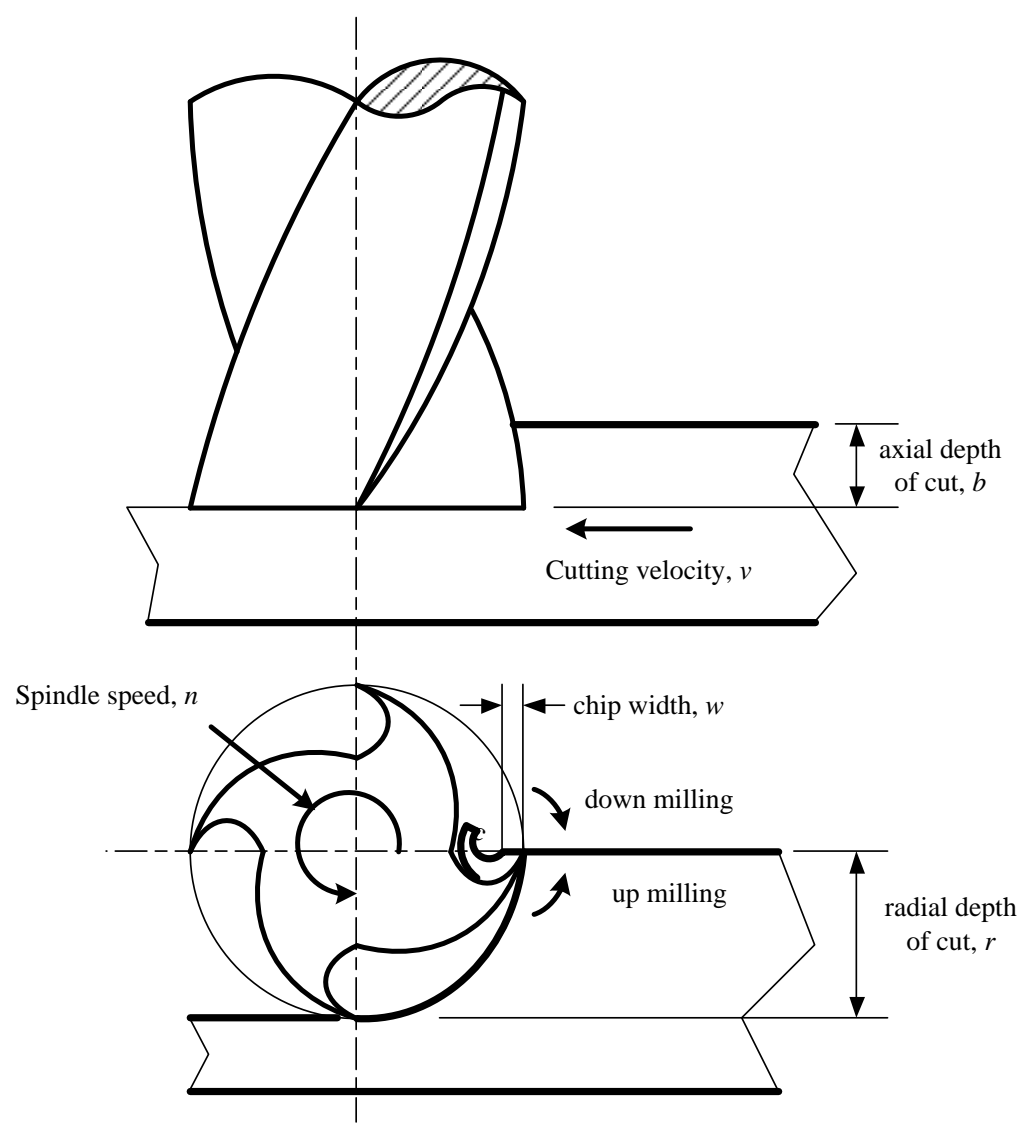

Figure 2. Cutting tool process parameters and type of milling operation

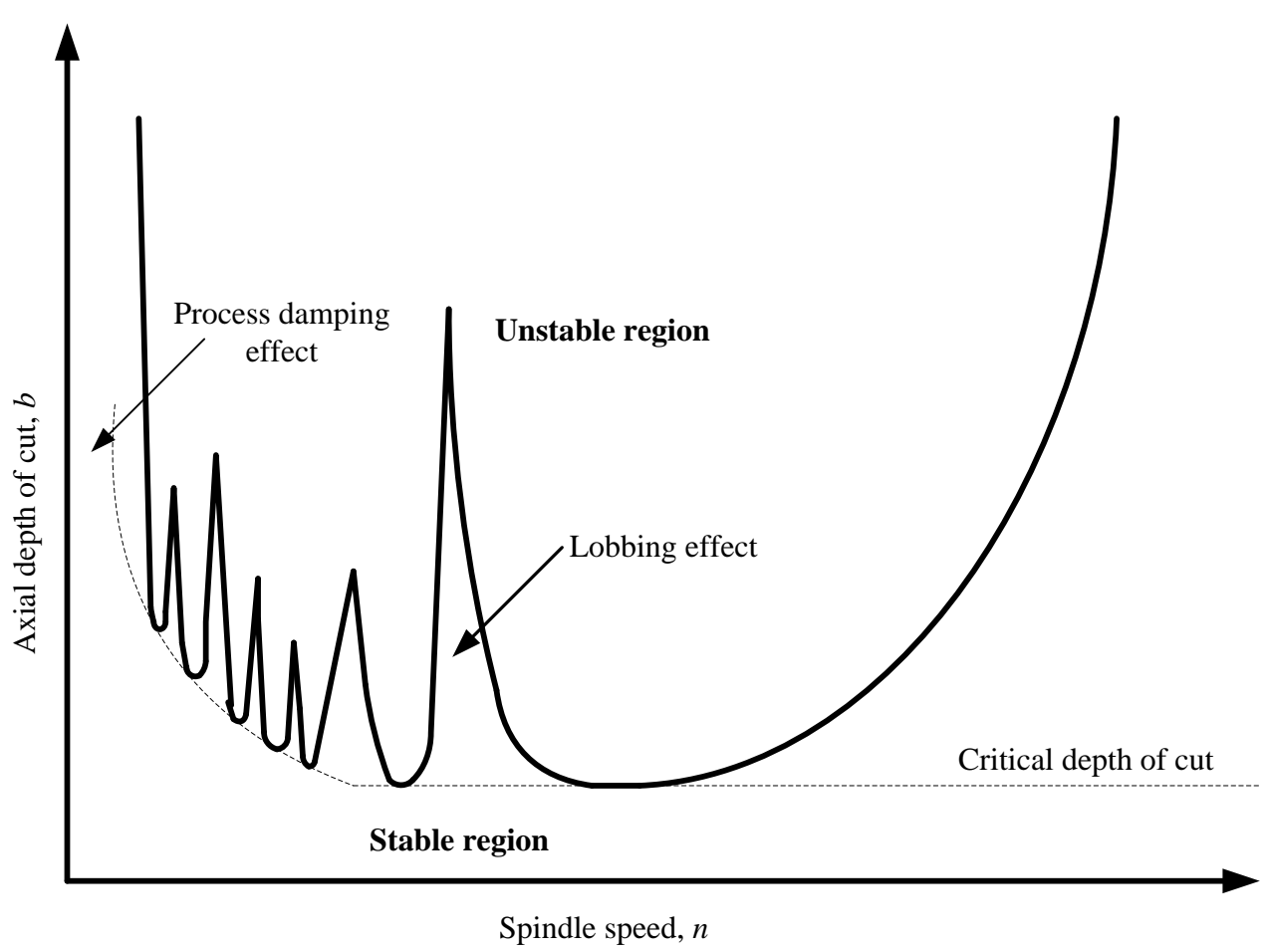

Figure 3. Stability lobes diagram. 


\section{OPTIMIZATION METHODS AND PROBLEMS}

The development of powerful computer tools has accelerated the optimization methods for solving machining problems. The optimization problem consists of three basic parameters that need to be considered: objective function, a set of unknowns or variables, and a set of constraints. For the machining problem, these problems can be solved by optimizing the parameters in processes, tools, and problem functions. The problem functions consist of constraint parameters and operation conditions referring to the problem to be solved. The objective function is named the cost function to minimize its value, fitness function to maximize its value, and error function to search its zero value (Fletcher, 1987).

Computer optimization methods for metal cutting operations can be classified as traditional, modern, and intelligent methods. Operational research or traditional methods are known as Geometric Programming (GP) (Walvekar \& Lambert, 1970; Jha, 1990; Koulamas, 1991; Wang, Rahman, Wong, \& Sun, 2005), Dynamic Programming (DP) (Sonmez, Baykasoglu, Dereli, \& Filiz, 1999; Wang et al., 2005), and Sequential Quadratic Programming (SQP) (Balakrishnan \& DeVries, 1985; Chua, Loh, Wong, \& Rahman, 1991; Yeo, Rahman, \& Wong, 1995; Stori \& Wright, 2001; Kurdi, Schmitz, Haftka, \& Mann, 2004; Kurdi, 2005; Maeda, Cao, \& Altintas, 2005; Abburi \& Dixit, 2007). However, the traditional method is based on a derivative technique, which faces problems when an objective function is used that cannot be differentiated. In addition, an objective function can also be a computer program or experimental data that are very subjective, and the constraint may also consist of differentiation parameters (Lin, 2002; Ghani, Choudhury, \& Hassan, 2004; Tsai \& Hsieh, 2005; Chang \& Lu, 2007). Therefore, modern technology is introduced to overcome the problems by applying a statistical approach, such as the Taguchi Method (Lin, 2002; Ghani et al., 2004; Tsai \& Hsieh, 2005; Chang \& Lu, 2007), Design of Experiment ( Vivancos, Luis, Costa, \& Ortiz, 2004; Stoic, Kopac, \& Cukor, 2005; Bajic, Lela, \& Zivkovic, 2008), and Response surface methodology ( Oktem, Erzurumlu, \& Kurtaran, 2005; Saikumar \& Shunmugan, 2008). Nevertheless, statistical methods can be trapped in local optimization, premature and not generalized because the equations used are obtained from experiment (Budak, 2000; Marian Wiercigroch, 2001; Budak, 2003). Thereby, intelligent techniques overcome the problem by introducing Hill Climbing (Budak, 2000; Budak, 2003; Baskar, Asokan, Saravanan, \& Prabhaharan,, 2006), Neural Networks (Westkämper \& Schmidt, 1998; El-Mounayri, Kishawy, \& Briceno, 2005), Simulated Annealing ( Juan, Yu, \& Lee, 2003; Wang et al., 2005), Tabu Search ((Budak, 2000; Budak, 2003; Baskar, Asokan, Prabhaharan, \& Saravanan, 2005), Genetic Algorithms (GA) (Li \& Li, 2000; Cus \& Balic, 2003; Ariffin \& Worden, 2004; Baskar et al., 2005; Onwubolu, 2005; Stoic et al., 2005; Wang et al., 2005; Baskar et al., 2006; Oktem, Erzurumlu, \& Erzincanli, 2006; Weinert, Zabel, Muller, \& Kersting, 2006; Yajun, Zhenliang, \& Minghui, 2006; Parent, Songmene, \& Kenne, 2007; Savas \& Ozay, 2007), Ant Colony Optimization (Baskar et al., 2005), Differential Evolution (DE) (Krishna, 2007; Saikumar et al., 2008), and Particle Swarm Optimization (PSO) Tandon, El-Mounayri, \& Kishawy, 2002; Kurdi et al., 2004; Baskar et al., 2005; Kurdi, 2005). Latest technology optimization can be applied in a virtual manufacturing environment, as proposed by Merdol and Altintas (2008a; 2008b).

Abuelnaga and El-Dardiry (1984) reviewed several mathematical approaches (GP, DP and SQP) for solving optimization problems in machining, while Aggarwal and Singh (2005) compiled turning machining optimization problems according to the 
conventional and most recent technologies. Mukherjee (2006) reviewed the advantages and disadvantages of machining optimization methods used in current research. In contrast, Appendix 1 summarizes the literature on the problems, techniques, and parameters of machining optimization. Machining problems can be classified into product quality, productivity, tool life and chatter. In short, GA and SQP are the methods predominantly used for solving most of the problems in machining, and they indicate that machining problems can be faced and solved by either conventional or intelligent methods. For this work, although GA is more popular than DE in current research, DE will be applied to optimize variable helix and variable pitch owing to its robustness and it being faster than GA (Tusar, Korosec, Papa, Kilipic, \& Silc, 2007). For instance, Mayer, Kinghorn and Archer, (2005) used a small population of DE with efficient, robust, and better results than GA when optimizing a beef model. A comparison of stochastic methods (GA, ES, PSO, DE, electromagnetic algorithm, and stigmergy algorithm) performed by Tusar et al. (2007) in optimizing universal motor geometries, showed that DE and the stigmergy algorithm improved the loss of power of the motor better than the other stochastic methods.

Additionally, DE is the only algorithm that can find consistently the optimal solution with a few function evaluations (Pener \& Littlefair, 2005), small population size, and the capability to escape local optimality with the mutation process (Saikumar Shunmugan, 2008). Thus, it can avoid rapid convergence. However, although DE cannot compete with a free search algorithm, it is better in terms of exploration ability and facing noisy data, than GA and PSO, when optimizing several constraint problems (Krishna, 2007). DE has also been applied successfully (Price, Storn \& Lampinen, 2005) in digital design, neural network learning, fuzzy decision-making problems, and optimization of heat exchangers. In machining optimization, Saikumar and Shunmugan (2008) applied DE to select the best cutting speed, feed rate, and depth of cut to achieve an optimum surface finish, while Krishna (2007) applied DE in grinding, when searching for a suitable process for minimizing surface grinding. In addition, SQP, as a popular conventional method, can be used to benchmark the results of DE. Kurdi et al. (2004; 2005) applied SQP to optimize a multi-objective function using a Pareto front approach, where each time a single objective was solved, the second objective was constrained until an optimal front was found. SQP can also transform nonlinear optimization problems into a quadratic sub-problem around an initial guess that gives better performance than PSO results. Therefore, based on the previous research and experience, DE and SQP will be used for optimizing the current problems.

\section{OPTIMIZATION IN CHATTER SUPPRESSION}

Regenerative instability is affected by many factors, such as the workpiece, tool material, machine stiffness, tool geometry, and cutting processes. On the other hand, milling stability is more complex owing to the rotation, multiple cutting teeth, periodic force, chip load direction, and multiple degrees of freedom of the structural dynamics (Tlusty, 2000 ). In order to show that the chatter of the system is mitigated, the stability limits should describe the increment from the original dynamics machine tools system. In suppressing chatter, certain methods require optimization to be taken into consideration. For example, spindle design (Liu \& Rouch, 1991; Maeda et al., 2005), tool path (Ariffin, Sims, \& Worden, 2004), cutting process (Kurdi et al., 2004; Budak et al., 2005; Kurdi, 2005; Tekeli \& Budak, 2007), and variable pitch require an optimization algorithm to be applied. 
The spindle is a main component in a machine tool where both the static and the dynamic spindle stiffness are related directly to the chatter problem. An appropriate spindle design is required, especially in optimizing the geometry to produce high productivity machining without chatter. Maeda et al. (2005) optimized bearing distribution along the spindle shaft using SQP. Finite element modeling (FEM) was applied to predict the frequency response function (FRF) of the spindle speed based on Tomoshenko beam theory. Integrated with chatter vibration stability, cutting speed, and axial depth of cut, the spindle drive configuration can be designed and optimized. Maximum critical depth of cut was included in the objective function, which changes according to the bearing location FRF and the number of flutes. Liu \& Rouch (1991) proposed an optimal passive dynamic absorber for the milling process. Before carrying out the passive control, a dynamic mass was to be connected with the optimized passive elements, such as the spring and damper. The objective function was chosen as the optimal critical depth of cut that could be applied in the wide range of spindle speeds. However, wide ranges of high torques and spindle speeds are required to ramp at high spindle speed.

Chatter stability is represented by depth of cut in the spindle speed function, as shown in Figure 3. It involves the cutting process parameters that should be optimized in order to minimize chatter. Thus, Kurdi et al. (2004; 2005), and Budak and Tekeli (2005; 2007) applied process optimization methods to suppress chatter. Kurdi et al. (2004; 2005) optimized spindle speed and depth of cut under stability conditions of chatter, in order to achieve high material removal rate and minimum surface location error by using a Time Finite Element Analysis (TFEA) numerical method. PSO and SQP were applied to search for two objective functions under a Pareto front approach where each time a single objective was solved, the second objective was constrained until the optimal front was found. An additional constraint with perturbed spindle speed was added to treat trapped SQP in local minima, which performed better than PSO because of the discontinuity trend. Both objective functions used $\mathrm{b}$ and $\mathrm{n}$ as parameters and constraints of dynamic map eigenvalues. Material removal rate (MRR) calculations also involved chip width as a constraint, in addition to depth of cut and spindle speed. As stated previously, spindle speed selection is impractical to apply owing to the availability and limited spindle speed of certain machines. However, an epsilon constraint, which can be applied easily to any optimization algorithm, is appropriate for solving multi-objective problems.

On the other hand, Budak and Tekeli $(2005 ; 2007)$ maximized the MRR while optimizing axial and radial depth of cut, without sacrificing chatter, by using an analytical method. Maximum MRR can be achieved at certain combinations of $b$ and $r$ while both $\mathrm{n}$ and the number of cutters are constant, and it is related to the FRF of the cutting tool change. From integrating the optimization with the computer-aided design/computer-aided manufacturing (CAD/CAM) system, machining time was reduced when applied to pocket machining. They used their own algorithm to optimize the machining process for maximum MRR, while at the same time, minimizing chatter and machining time. However, maximizing radial and axial depth of cut requires a twist optimization approach, which takes time to achieve optimum immersion conditions.

Variable geometry can be optimized to reduce chatter in generating low cutting force, high material removal rate, and a precise product by using several approaches. For example, Altintas, Engin and Budak (1999) emphasized maximizing axial depth of cut when the regenerative phase $\in$ shifts to $90^{\circ}$; the phase changes when using different $\mathrm{n}, \mathrm{f}_{\mathrm{c}}$ and $\mathrm{b}$. To optimize variable pitch angles, a manual mathematical calculation was 
applied by considering specific spindle speeds and chatter frequencies that minimize chatter. Using variable pitch tools, Shirase and Altintas (1996) minimized the force and location error. However, modifications of the variable pitch range are small because of phase angle constraints in maintaining a no-chatter condition. Additionally, Budak (2000; 2003) modeled and optimized a non-constant pitch angle cutter model with an analytical stability model. A simple equation based on $\mathrm{HC}$ was used to determine optimal pitch angles from stability and pitch variation. A linear pitch variation was used that gives higher stability, rather than non-linear variation for which tool manufacture is difficult. Thus, the spindle speed and chatter frequency need to be tuned to optimize pitch angles at constant depth of cut. Both the phase difference and chatter frequency were set as constraints to ensure that higher stability was accomplished. A variable pitch cutter is appropriate for low speed machining; in addition to reducing force, it also does not increase cost, and only needs measurement analysis. However, at a certain pitch variation, it is suitable only under a limited range of frequencies and speeds.

In contrast, Olgac and co-authors (Nejat \& Rifat, 2005; Fazelinia \& Olgac, 2006; Olgac \& Sipahi, 2007a; 2007b) maximized MRR in simultaneous machining with an irregular pitch cutter using the cluster treatment of characteristic roots (CTCR) algorithm. The algorithm has the capability to optimize unstable variable pitch at certain values of $b$ and $n$. It is based on the characteristic equation of the CTCR, at certain $b$, to represent two time delays in pitch ratio and $n$ variation. The characteristic equation depends on the number of flutes, spindle speed, and different depth of cut, to give different optimal values by using the time delays. CTCR with time delay pitch angle and spindle speed mapping with a certain depth of cut. In addition, variable pitch results need to consider the chip evacuation phenomenon, particularly at small angles, which was reported by Altintas et al. (1999), and Olgac and Sipahi (2007) who continued the same approach with a 6-flute cutter. However, no experimental implementation results have been discussed.

\section{CONCLUSIONS}

In the literature, it can be found that machining optimization focuses on spindle design, tool path, cutting process, and variable pitch. Various algorithms that can be applied in optimization of machining problems; however, DE is the most appropriate for use in chatter suppression, being less time consuming, locally optimal, and more robust than both GA, despite its wide applications and SQP, which is a famous conventional algorithm.

\section{ACKNOWLEDGMENTS}

The author gratefully acknowledges the financial support from the University Malaysia Pahang (UMP) under UMP RDU Short Grant (RDU110305).

\section{REFERENCES}

Abburi, N., \& U. Dixit, U. (2007). Multi-objective optimization of multipass turning processes. The International Journal of Advanced Manufacturing Technology, 32(9), 902-910. 
Abuelnaga, A. M., \& El-Dardiry, M. A. (1984). Optimization Methods for Metal Cutting. International Journal of Machine Tool Design and Research, 24(1), 1118.

Agapiou, J. S. (1992). Optimization of Multistage machining Systems, Part 1:Mathematical Solution. Journal of engineering for industry, 114, 524-531.

Aggarwal, A., \& Singh, H. (2005). Optmization of Machining Technique-A retrospective and literature review. Sadhand, 30(6), 699-711.

Altintas, Y., Engin, S., \& Budak, E. (1999). Analytical stability prediction and design of variable pitch cutters. Journal of Manufacturing Science and Engineering, Transactions of the ASME, 121(2), 173-178.

Ariffin, M. K. A., Sims, N. D., \& Worden, K. (2004). Genetic optimisation of machine tool paths. 6th International Conference on Adaptive Computing In Design And Manufacture In 'Adaptive Computing in Design and Manufacture VI, Bristol., Springer-Verlag

Armarego, E. J. A., Smith, A. J. R., \& Wang, J. (1993). Constrained Optimization Strategies and CAM Software for Single-pass Peripheral Milling. International Journal of Production Research, 31(9), 2139-2160.

Baek, D. K., Ko, T. J., \& Kim, H. S. (2001). Optimization of feedrate in a face milling operation using a surface roughness model. International Journal of Machine Tools and Manufacture, 41(3), 451-462.

Bajic, D., Lela, B., \& Zivkovic, D. (2008). Modeling of machined surface roughness and optimization of cutting parameters in face milling. Metalurgija, 47(4), 331334.

Balakrishnan, P., \& DeVries, M. F. (1985). Sequential estimation of machinibility parameters for adaptive optimization of machinibility data base systems. Journal of Engineering for Industry, 107, 159-166.

Baskar, N., Asokan, P., Prabhaharan, G., \& Saravanan, R. (2005). Optimization of machining parameters for milling operations using non-conventional methods. The International Journal of Advanced Manufacturing Technology, 25(11), 1078-1088.

Baskar, N., Asokan, P., Saravanan, R., \& Prabhaharan, G. (2006). Selection of optimal machining parameters for multi-tool milling operations using a memetic algorithm. Journal of Materials Processing Techology, 174(1), 239-249.

Budak, E. (2000). Improving productivity and part quality in milling of titanium based impellers by chatter suppression and force control. CIRP Annals Manufacturing Technology, 49(1), 31-36.

Budak, E. (2003). An analytical design method for milling cutters with non-constant pitch to increase stability, Part 1: Theory and Part 2: Application. Journal of Manufacturing Science and Engineering, 125, 29-38.

Budak, E., \& Tekeli, A. (2005). Maximizing chatter free material removal rate in milling through optimal selection of axial and radial depth of cut. CIRP Annals Manufacturing Technology, 54(1), 353-356.

By Chen, J. S., Huang, Y. K., \& Chen, M. S. (2005). Feedrate optimization and tool profile modification for the high-efficiency ball-end milling process. International Journal of Machine Tools and Manufacture, 45(9), 1070-1076.

Chang, C. K., \& Lu, H. (2007). Design optimization of cutting parameters for side milling operations with multiple performance characteristics. The International Journal of Advanced Manufacturing Technology, 32(1), 18-26. 
Chua, M. S., Loh, H. T., Wong, Y. S., \& Rahman, M. (1991). Optimization of cutting conditions for multi-pass turning operations using sequential quadratic programming. Journal of Materials Processing Technology, 28(1-2), 253-262.

Cus, F., \& Balic, J. (2003). Optimization of cutting process by GA approach. Robotics and Computer-Integrated Manufacturing, 19(1-2), 113-121.

El-Mounayri, H., Kishawy, H., \& Briceno, J. (2005). Optimization of CNC ball end milling: a neural network-based model. Journal of Materials Processing Technology, 166(1): 50-62.

Fazelinia, H., \& Olgac, N. (2006). Optimum Consitions for variable Pitch Milling. ASME International Mechanical Engineering Congress and Exposition. Illlinois, pp. 1-8.

Fletcher, R. (1987). Practical Methods of Optimization. West Sussex: John Wilet \& Sons.

Ghani, J. A., Choudhury, I. A., \& Hassan, H. H. (2004). Application of Taguchi method in the optimization of end milling parameters. Journal of Materials Processing Technology, 145(1), 84-92.

Jha, N. K. (1990). A discrete data base multiple objective optimization of milling operation through geometric programming. Journal of Engineering for Industry, $112,368-374$.

Juan, H., Yu, S. F., \& Lee, B. Y. (2003). The optimal cutting-parameter selection of production cost in HSM for SKD61 tool steels. International Journal of Machine Tools and Manufacture, 43(7), 679-686.

Kim, K. K., Kang, M. C., Kim, J. S., Jung, Y. H., \& Kim, N. K. (2002). A study on the precision machinability of ball end milling by cutting speed optimization. Journal of Materials Processing Technology, 130, 357-362.

Koulamas, C. (1991). Simultaneous determination of optimal machining conditions and tool replacement policies in constrained machining economics problems by geometric programming. International Journal of Production Research, 29(12), 2407-2421.

Krishna, A. (2007). Selection of optimal conditions in the surface grinding process using a differential evolution approach. Proceedings of the Institution of Mechanical Engineers, Part B: Journal of Engineering Manufacture, 221(7), 1185-1192.

Kurdi, M. H. (2005). Robust multicriteria optimization of surface location error and material removal rate in high speed milling under uncertainty. Department of Mechanical and Aerospace Engineering, University of florida.

Kurdi, M. H., Schmitz, T. L., Haftka, R. T., \& Mann, B. P. (2004). Simultaneous optimization of material removal rate and part accuracy in high speed milling. ASME International Mechanical Engineering Congress and Exposition (IMECE), pp. 1001-1009.

Li, H., \& Li, X. (2000). Modelling and simulation of chatter in milling using a predictive force model. International Journal of Machine Tools and Manufacture, 40(14), 2047.

Lin, T .R. (2002). Optimisation technique for face milling stainless steel with multiple performance characteristics. The International Journal of Advanced Manufacturing Technology, 19(5), 330-335.

Liu, K. J., \& Rouch, K. E. (1991). Optimal passive vibration control of cutting process stability in milling. Journal of Materials Processing Technology, 28(1-2), 285294. 
Maeda, O., Cao, Y., \& Altintas, Y. (2005). Expert spindle design system. International Journal of Machine Tools and Manufacture, 45(4-5), 537-548.

Marian Wiercigroch, E. B. (2001). Sources of nonlinearities, chatter generation and suppression in metal cutting. Philosophical Transactions of the Royal Society A: Mathematical, Physical and Engineering Sciences, 359(1781), 663-693.

Mayer, D. G., Kinghorn, B. P., \& Archer, A. A. (2005). Differential evolution - an easy and effiecient evolutionary algorithm for model optimisation. Agricultural Systems, 83, 315-328.

Merchant, M. E. (1945). Mechanics of the metal cutting process. ASME Journal of Applied Physics, 16(5), 318-324.

Merdol, D., \& Altintas, Y. (2008a). Virtual cutting and optimization of milling operations-Part 1: Process simulation Part 2: Optimization and feedrate scheduling. Journal of Manufacturing Science and Engineering, 130(5), 100415.

Merdol, D., \& Altintas, Y. (2008b). Virtual cutting and optimization of three-axis milling processes. International Journal of Machine Tools and Manufacture, 48, 1063-1071.

Mukherjee, I., \& Ray, P. K. (2006). A review of optimization techniques in metal cutting processes. Computers \& Industrial Engineering, 50(1), 15-34.

Nejat, O., \& Rifat, S. (2005). A unique methodology for chatter stability mapping in simultaneous machining. Journal of Manufacturing Science and Engineering, 127(4), 791-800.

Oktem, H., Erzurumlu, T., \& Erzincanli, F. (2006). Prediction of minimum surface roughness in end milling mold parts using neural network and genetic algorithm. Materials and Design, 27(9), 735-744.

Oktem, H., Erzurumlu, T., \& Kurtaran, H. (2005). Application of response surface methodology in the optimization of cutting conditions for surface roughness. Journal of Materials Processing Technology, 170(1-2), 11-16.

Olgac, N., \& Sipahi, R. (2007a). Dynamic and stability of variable pitch milling. Journal of Vibration and Control, 13(7), 1031-1043.

Olgac, N., \& Sipahi, R. (2007b). Dynamics and stability of variable pitch milling. Journal of Vibration \& Control, 13, 1031-1043.

Onwubolu, G. (2005). Optimization of milling operations for the selection of cutting conditions using Tribes. Proceedings of the Institution of Mechanical Engineers, Part B: Journal of Engineering Manufacture, 219(10), 761-771.

Parent, L., Songmene, V., \& Kenne, J. P. (2007). A generalised model for optimising and end milling operation. Production Planning and Control, 18(4), 319-337.

Pener, K., \& Littlefair, G. (2005). Free Search - A Comparative Analysis. Information Science, 172, 173-193.

Price, K. V., Storn, R. M., \& Lampinen, J. A. (2005). Differential evolution a practical approach to global optimization. Berlin Heidelberg: Springer.

Saikumar, S., \& Shunmugan, M. S. (2008). Parameter selection based on surface finish in high speed finish in high speed end milling using differential evolution. Materials and Manufacturing Processes, 21(4), 341-347.

Savas, V., \& Ozay, C. (2007). The optimization of the surface roughness in the process of tangential turn-milling using genetic algorithm. The International Journal of Advanced Manufacturing Technology, 37(3-4), 335-340. 
Shirase, K., \& Altintas, Y. (1996). Cutting force and dimensional surface error generation in peripheral milling with variable pitch helical end mills. International Journal of Machine Tools \& Manufacture, 36(5), 567-584.

Sonmez, A. I., Baykasoglu, A., Dereli, T., \& Filiz, I. H. (1999). Dynamic optimization of multipass milling operations via geometric programming. International Journal of Machine Tools and Manufacture, 39(2), 297-320.

Sorby, K., Tonnessen, K., Torjusen, J. E., \& Rasch, F. O. (2000). Improving high speed flank milling operations in multi-axis machines. CIRP Annals - Manufacturing Technology, 49(1), 371-374.

Stephenson, D. A., \& Agapiou, J. S. (2006). Metal cutting: Theory and practice. Boca Raton: Taylor \& Francis Group.

Stoic, A., Kopac, J., \& Cukor, G. (2005). Testing of machinability of mould steel 40CrMnMo7 using genetic algorithm. Journal of Materials Processing Technology, 164-165, 1624-1630.

Stori, J. A., \& Wright, P. K. (2001). Parameter space decomposition for selection of the axial and radial depth of cut in endmilling. Journal of Manufacturing Science and Engineering, 123(4), 654-664.

Stori, J. A., Wright, P. K., \& King, C. (1999). Integration of process simulation in machining parameter optimization. Journal of Manufacturing Science and Engineering, 121(1), 134-143.

Tandon, V., El-Mounayri, H. \& Kishawy, H. (2002). NC end milling optimization using evolutionary computation. International Journal of Machine Tools and Manufacture, 42(5), 595-605.

Tekeli, A., \& Budak, E. (2007). Maximization of chatter free material removal rate in end milling using analytical methods. Machining Science and Technology, 9(2), 147-167.

Tlusty, J. (2000). Manufacturing process and equipment. New Jersey: Prentice Hall.

Tolouei-Rad, M., \& Bidhendi, I. M. (1997). On the optimization of machining parameters for milling operations. International Journal of Machine Tools and Manufacture, 37(1), 1-16.

Tsai, Y. C., \& Hsieh, J. M. (2005). An analysis of cutting-edge curves and machining performance in the Inconel 718 machining process. The International Journal of Advanced Manufacturing Technology, 25(3), 248-261.

Tusar, T., Korosec, P., Papa, G., Kilipic, B., \& Silc, J. (2007). A comparative study of stochastic optimization methods in electrical motor design. Artificial Intelligence, 27(2), 101-111.

Vivancos, J., Luis, C. J., Costa, L., \& Ortiz, J. A. (2004). Optimal machining parameters selection in high speed milling of hardened steels for injection moulds. Journal of Materials Processing Technology, 155-156, 1505-1512.

Walvekar, A. G., \& Lambert, B. K. (1970). An Application of Geometric Programming to Machining Variable Selection. International Journal of Production Research, $8(3), 241-245$.

Wang, J. (1998). Computer-aided economic optimization of end-milling operations. International Journal of Production Economics, 54(3), 307-320.

Wang, Z. G., Rahman, M., Wong, Y. S., \& Sun, J. (2005). Optimization of multi-pass milling using parallel genetic algorithm and parallel genetic simulated annealing. International Journal of Machine Tools and Manufacture, 45(15), 1726-1734.

Weinert, K., Zabel, A., Muller, H., \& Kersting, P. (2006). Optimizing of NC tool paths for five-axis milling using evolutionary algorthms on wavelets. Proc. 8th Annual 
Conference on Genetic and Evolutionary Computation, Seattle, Washington, pp. 1809-1816.

Westkämper, E., \& Schmidt, T. (1998). Computer-assisted manufacturing process optimization with neural networks. Journal of Intelligent Manufacturing, 9(4), 289-294.

Yajun, J., Zhenliang, L., \& Minghui, L. (2006). Application of fuzzy and rough sets theory in the optimization of machining parameters for mold milling operations. The International Journal of Advanced Manufacturing Technology, 28(11), 1071-1077.

Yeo, S. H., Rahman, M., \& Wong, Y. S. (1995). A tandem approach to selection of machinability data. The International Journal of Advanced Manufacturing Technology, 10(2), 79-86.

\section{APPENDIX 1}

Summary of problems, techniques and parameters used in optimization problems in machining

\begin{tabular}{|c|c|c|c|}
\hline No & Problem & Technique & Parameters commonly used \\
\hline 1 & $\begin{array}{l}\text { Production } \\
\text { cost/time/profit } \\
\mathrm{s}\end{array}$ & $\begin{array}{l}\text { Genetic Algorithms } \\
\text { (Baskar et al., 2006; } \\
\text { Yajun et al., 2006; Parent } \\
\text { et al., 2007) } \\
\text { Simulated Annealing } \\
\text { (Juan et al., 2003) } \\
\text { Sequential Quadratic } \\
\text { Programming (Chua et } \\
\text { al., 1991; Stori, Wright } \\
\text { \& King, 2001; Maeda et } \\
\text { al., 2005) } \\
\text { Specific algorithms } \\
\text { (Armarego, Smith \& } \\
\text { Wang, 1993) } \\
\text { Hill Climbing (Baskar et } \\
\text { al., 2006) } \\
\text { Memetic Algorithm } \\
\text { (Baskar et al., 2006) }\end{array}$ & $\begin{array}{l}\text { Machine power (Chua et al., } \\
\text { 1991; Armarego et al., } \\
\text { 1993; Baskar et al., 2006; } \\
\text { Yajun et al., 2006; Parent et } \\
\text { al., 2007) } \\
\text { Chip width (Chua et al., } \\
\text { 1991; Armarego et al., } \\
\text { 1993; Juan et al., 2003; } \\
\text { Baskar et al., 2006; Yajun et } \\
\text { al., 2006) } \\
\text { Cutting force (Armarego et } \\
\text { al., 1993; Baskar et al., } \\
\text { 2006) } \\
\text { Surface roughness (Baskar } \\
\text { et al., 2006; Yajun et al., } \\
\text { 2006; Parent et al., 2007) } \\
\text { Tool life (Juan et al., 2003) } \\
\text { Cutting speed (Chua et al., } \\
\text { 1991; Armarego et al., } \\
\text { 1993; Juan et al., 2003; } \\
\text { Yajun et al., 2006; Parent et } \\
\text { al., 2007) } \\
\text { Spindle speed (Baskar et al., } \\
\text { 2006; Parent et al., 2007) } \\
\text { Axial depth of cut (Chua et } \\
\text { al., 1991; Stori et al., 2001; } \\
\text { Juan et al., 2003; Maeda et } \\
\text { al., 2005; Yajun et al., 2006; }\end{array}$ \\
\hline
\end{tabular}




\begin{tabular}{|c|c|c|c|}
\hline & & & $\begin{array}{l}\text { Parent et al., 2007) } \\
\text { Radial depth of cut (Stori et } \\
\text { al., 2001) }\end{array}$ \\
\hline 2 & $\begin{array}{l}\text { Material } \\
\text { removal rate }\end{array}$ & $\begin{array}{l}\text { Dynamic Programming } \\
\text { (Sonmez et al., 1999) } \\
\text { Neural Network (El- } \\
\text { Mounayri et al., 2005) } \\
\text { Sequential Quadratic } \\
\text { Programming (Stori et } \\
\text { al., 1999) } \\
\text { Geometric Programming } \\
\text { (Walvekar et al., 1970) } \\
\text { Specific Algorithm ( By } \\
\text { Chen, Huang \& Chen, } \\
\text { 2005) }\end{array}$ & $\begin{array}{l}\text { Chip width (Walvekar et al., } \\
\text { 1970; Sonmez et al., 1999; } \\
\text { By Chen et al., 2005; El- } \\
\text { Mounayri et al., 2005) } \\
\text { Cutting speed (Walvekar et } \\
\text { al., 1970; El-Mounayri et } \\
\text { al., 2005) } \\
\text { Axial depth of cut (El- } \\
\text { Mounayri et al., 2005) } \\
\text { Radial depth of cut (El- } \\
\text { Mounayri et al., 2005) } \\
\text { Tool life (Walvekar et al., } \\
\text { 1970) } \\
\text { Machine power (Walvekar } \\
\text { et al., 1970) } \\
\text { Surface roughness (Stori et } \\
\text { al., 1999) }\end{array}$ \\
\hline 3 & Surface finish & 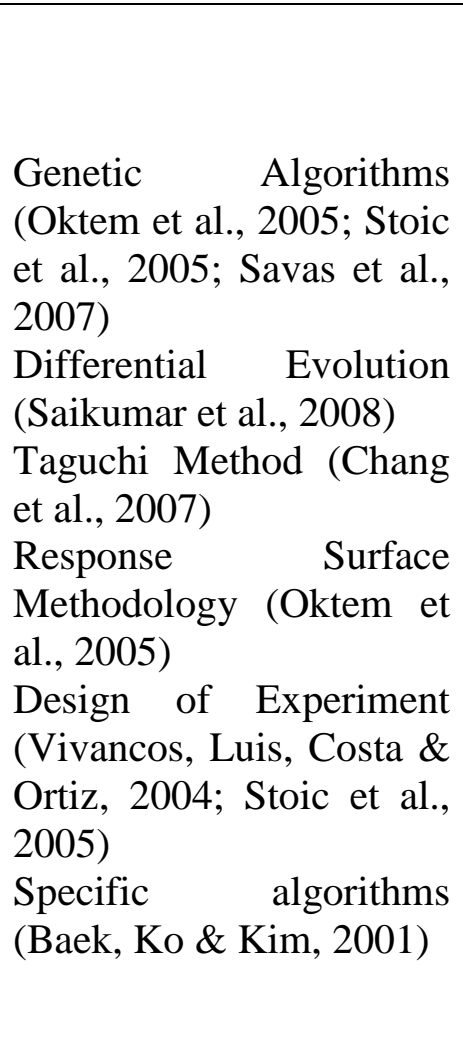 & $\begin{array}{l}\text { Chip width (Baek et al., } \\
\text { 2001; Vivancos et al., 2004; } \\
\text { Oktem et al., 2005; Stoic et } \\
\text { al., 2005; Chang et al., } \\
\text { 2007; Savas et al., 2007) } \\
\text { Cutting speed (Vivancos et } \\
\text { al., 2004; Oktem et al., } \\
\text { 2005; Stoic et al., 2005; } \\
\text { Chang et al., 2007; Savas et } \\
\text { al., 2007) } \\
\text { Spindle speed (Savas et al., } \\
\text { 2007) depth of cut } \\
\text { Axial et al., 2004; } \\
\text { (Vivancos et } \\
\text { Oktem et al., 2005; Stoic et } \\
\text { al., 2005; Chang et al., } \\
\text { 2007; Savas et al., 2007; } \\
\text { Saikumar et al., 2008) } \\
\text { Radial depth of cut } \\
\text { (Vivancos et al., 2004; } \\
\text { Oktem et al., 2005; Chang } \\
\text { et al., 2007) }\end{array}$ \\
\hline 4 & Tool life & $\begin{array}{l}\text { Specific algorithms } \\
\text { (Balakrishnan et al., } \\
\text { 1985) }\end{array}$ & $\begin{array}{l}\text { Chip width (Balakrishnan et } \\
\text { al., 1985) } \\
\text { Cutting speed (Balakrishnan } \\
\text { et al., 1985) } \\
\text { Axial depth of cut } \\
\text { (Balakrishnan et al., 1985) }\end{array}$ \\
\hline
\end{tabular}




\begin{tabular}{|c|c|c|c|}
\hline 5 & Chatter & $\begin{array}{l}\text { Genetic Algorithms } \\
\text { (Ariffin and Worden, } \\
\text { 2004) } \\
\text { Hill Climbing (Budak, } \\
\text { 2000; Budak, 2003) } \\
\text { Specific algorithms } \\
\text { (Altintas et al., 1999; } \\
\text { Budak et al., 2005; Nejat } \\
\text { et al., 2005; Fazelinia et } \\
\text { al., 2006; Olgac et al., } \\
\text { 2007; Tekeli et al., 2007) }\end{array}$ & $\begin{array}{l}\text { Material removal rate } \\
\text { (Budak et al., 2005; Tekeli } \\
\text { et al., 2007) } \\
\text { Spindle speed (Altintas et } \\
\text { al., 1999; Budak, 2000; } \\
\text { Budak, 2003; Budak et al., } \\
\text { 2005; Nejat et al., 2005; } \\
\text { Fazelinia et al., 2006; Olgac } \\
\text { et al., 2007; Tekeli et al., } \\
\text { 2007) } \\
\text { Cutting speed } \\
\text { Axial depth of cut (Budak, } \\
\text { 2000; Budak, 2003; Budak } \\
\text { et al., 2005; Nejat et al., } \\
\text { 2005; Fazelinia et al., 2006; } \\
\text { Olgac et al., 2007; Tekeli et } \\
\text { al., 2007) } \\
\text { Radial depth of cut } \\
\text { (Budak et al., 2005; Tekeli } \\
\text { et al., 2007) } \\
\text { Phase angle (Budak, 2000; } \\
\text { Budak, 2003) } \\
\text { Chatter frequency (Altintas } \\
\text { et al., 1999; Budak, 2000; } \\
\text { Budak, 2003) } \\
\text { Tool path (Ariffin M K A, } \\
\text { 2004) } \\
\text { Pitch angle (Altintas et al., } \\
\text { 1999; Budak, 2000; Budak, } \\
\text { 2003; Nejat et al., 2005; } \\
\text { Fazelinia et al., 2006; Olgac } \\
\text { et al., 2007) }\end{array}$ \\
\hline 6 & $\begin{array}{l}\text { Combined } \\
\text { problems }\end{array}$ & $\begin{array}{l}\text { Particle } \\
\text { Optimization (Kurdi et } \\
\text { al., 2004; Kurdi, 2005) } \\
\text { Sequential Quadratic } \\
\text { Programming (Yeo et al., } \\
\text { 1995; Kurdi et al., 2004; } \\
\text { Kurdi, 2005; Abburi et } \\
\text { al., 2007) } \\
\text { Genetic Algorithms (Cus } \\
\text { et al., 2003; Baskar et al., } \\
\text { 2005; Onwubolu, 2005; } \\
\text { Wang et al., 2005; Abburi } \\
\text { et al., 2007) } \\
\text { Specific algorithms } \\
\text { (Agapiou, 1992; Tolouei- } \\
\text { Rad and Bidhendi, 1997; } \\
\text { Wang, 1998; Sorby, }\end{array}$ & $\begin{array}{l}\text { Machine power (Koulamas, } \\
\text { 1991; Agapiou, 1992; } \\
\text { Tolouei-Rad et al., 1997; } \\
\text { Wang, 1998; Tandon et al., } \\
\text { 2002; Cus et al., 2003; Wang } \\
\text { et al., 2005; Abburi et al., } \\
\text { 2007) } \\
\text { Surface roughness (Agapiou, } \\
\text { 1992; Tolouei-Rad et al., } \\
\text { 1997; Wang, 1998; Tandon } \\
\text { et al., 2002; Onwubolu, } \\
\text { 2005; Abburi et al., 2007) } \\
\text { Tool life (Onwubolu, 2005; } \\
\text { Abburi et al., 2007) } \\
\text { Cutting speed (Jha, 1990; } \\
\text { Koulamas, 1991; Yeo et al., } \\
\text { 1995; Tolouei-Rad et al., }\end{array}$ \\
\hline
\end{tabular}




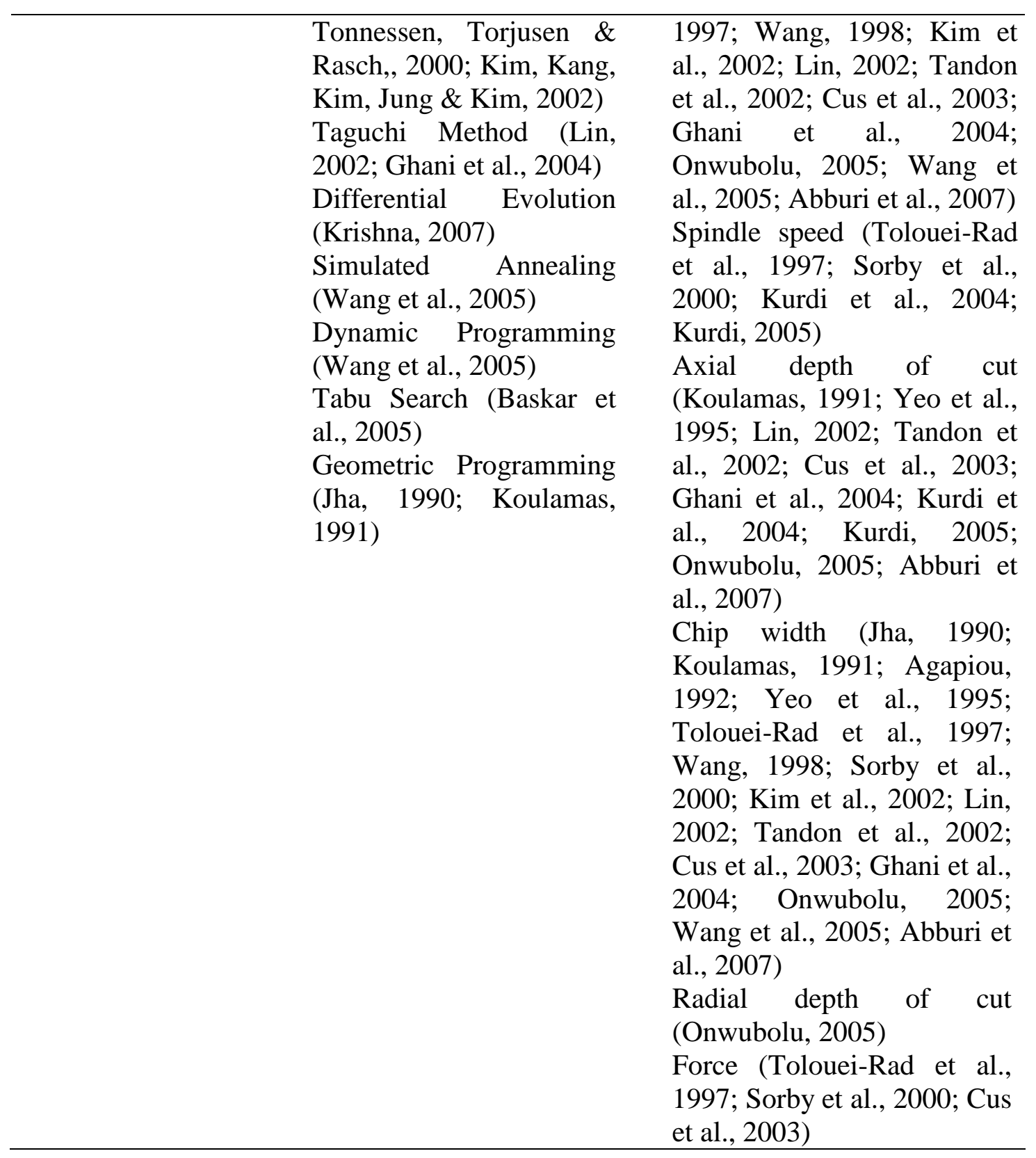

